Vol. 19(2010): 69-80.

\title{
Effect of substrate type on the field performance and chemical composition of highbush blueberry cr. Patriot
}

\author{
Ireneusz Ochmian ${ }^{1}$, Józef Grajkowski ${ }^{1}$ and Katarzyna Skupień ${ }^{2 *}$ \\ ${ }^{1}$ Department of Pomology, West Pomeranian University of Technology, Szczecin ul. Janosika 8, \\ 71-432 Szczecin, Poland \\ ${ }^{2}$ Department of Plant Raw Materials Processing and Storage, West Pomeranian University of Technology, \\ Szczecin, ul. Stowackiego 17, 71-434 Szczecin, Poland, \\ *e-mail: kskupien@agro.ar.szczecin.pl
}

\begin{abstract}
The aim of a 3-year study was to compare the effect of substrate type (peat, sawdust and cocoa husk) on the yield, fruit quality, general and phenolic composition, and antioxidant activity of highbush blueberry (Vaccinium corymbosum L.) cultivar Patriot. The largest berries and the highest yield were obtained from bushes grown in sawdust $\left(3.661 \mathrm{~kg} \mathrm{ha}^{-1}\right)$. Berries from bushes grown in cocoa husk had the highest content of $\mathrm{N}\left(14.25 \mathrm{~g} \mathrm{~kg}^{-1}\right), \mathrm{P}\left(1.17 \mathrm{~g} \mathrm{~kg}^{-1}\right), \mathrm{K}\left(6.51 \mathrm{~g} \mathrm{~kg}^{-1}\right)$, and $\mathrm{Zn}\left(8.78 \mathrm{mg} \mathrm{kg}^{-1}\right)$, as well as $\mathrm{P}\left(1.26 \mathrm{~g} \mathrm{~kg}^{-1}\right)$ and $\mathrm{K}$ $\left(6.99 \mathrm{~g} \mathrm{~kg}^{-1}\right)$ in the leaves. Both the leaves and fruits of plants grown in sawdust had higher $\mathrm{Cu}$ concentrations (3.89 and $3.01 \mathrm{mg} \mathrm{kg}^{-1}$ ). Berries from sawdust-grown bushes had the highest soluble solids $(13.1 \%)$

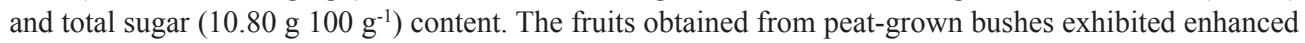
antioxidant capacity $\left(38.6 \mu \mathrm{mol}\right.$ Trolox $\left.\mathrm{g}^{-1}\right)$. However, the highest levels of phenolics were noted in berries

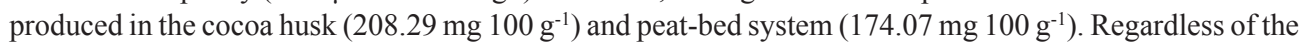
type of substrate used, the following phenols were identified (in descending order): anthocyanins $>$ chlorogenic acid $>$ flavonols. Delphinidin-glycosides were the most abundant pigments, and cyanidin, peonidin, petunidin, and malvidin-glycosides were also detected. Total flavonol content (quercetin derivatives and kaempferol 3-rutinoside) was not significantly affected by the type of substrate.
\end{abstract}

Key-words: Vaccinium corymbosum, yield, firmness, macro- and microelements, phenolics 
Ochmian, I. et al. Effect of substrates on highbush blueberry 'Patriot'

\section{Introduction}

Highbush blueberries (Vaccinium corymbosum L.), among other members of the Ericaceae family, are considered to be a rich source of phenolic compounds and are known for their antioxidant properties (Kalt et al., 1999, Zheng and Wang, 2003, Castrejón et al. 2008). Due to their chemical composition, blueberries are highlighted as one of the healthiest foodstuffs (Kader et al., 1996, Mainland et al. 2002). Because of its value, the species has been cultivated for years in North America. The first breeding project was launched in 1908 in Florida (Lyrene 1997), and soon afterwards highbush blueberries were imported from the USA to Europe (Strik 2005).

In Poland, the first experiments involving highbush blueberry cultivation were undertaken in 1946, while the development of large-scale production methods began in 1976. According to the results of field trials, Patriot was one of the cultivars recommended for growing in Poland (Smolarz 2006). A considerable increase in blueberry production has been recently observed in Poland. In 2006 Poland took $1^{\text {st }}$ place in Europe with regard to the highbush blueberry growing area, and blueberry production reached 8,000 t, which gave us the second place after Germany $(10,000 \mathrm{t})$ (Internetowa giełda rolna fresh-market 2009).

The highbush blueberry requires specific growing conditions including the right site, high in organic matter, appropriate water and air drainage, low pH, and adequate moisture (Kozinski 2006). On the one hand, this species allows the use of land which as a result of its high acidity is not suitable for other crops (Ciordia et al. 2006). On the other hand, such soils are less and less available, which hinders the establishment of new plantations. These factors have necessitated the search for and the development of modified soil systems.

An improvement in soil conditions can be achieved by using organic mulch materials, like peat with low $\mathrm{pH}$, sawdust, or coniferous bark. The application of mulches contributes to the loosening of the higher strata of soil thus improving root penetration (Kozinski 2006). In the USA, cotton by-products, pecan hulls (Krewer et al. 2002), leafmould compost, pit-coal ash, sludge from sewage treatment plants (Black et al. 2002), and conifer needle litter (Entrop 2000) are used for mulching purposes. From the practical and economic point of view, the components used for substrates and mulching should be relatively cheap, easily accessible, and should meet the habitat requirements of a given species. Therefore, the use of agricultural and forest by-products for this purpose seems to be fully justified.

The objective of the present study was to evaluate the influence of three types of substrate (cocoa husk, sawdust and peat) on the yield, fruit quality (fruit size and firmness), bush growth rate, fruit chemical composition (the content of soluble solids, total sugar, L-ascorbic acid, $\mathrm{NO}_{3}^{-}, \mathrm{NO}_{2}^{-}$, phenolics, macro- and microelements, titratable acidity, juice efficiency, antioxidant activity), macroand microelement concentrations in the leaves of highbush blueberry cv. Patriot.

\section{Materials and methods}

The experiment was carried out in the spring of 2001 at the Experimental Station Rajkowo near Szczecin in heavy soil of neutral reaction ( $\mathrm{pH} 7.1)$. The purpose of field trials was to evaluate highbush blueberry cultivation in three different substrates placed in the trenches, $35 \mathrm{~cm}$ deep and $100 \mathrm{~cm}$ wide $\left(0.35 \mathrm{~m}^{3}\right.$ medium per $\mathrm{m}$ of row length). Acidic muck soil (peat), conifer sawdust from a local sawmill, and cocoa husk - a by-product obtained from the Chocolate Confectionery Plant 'Gryf' in Szczecin were used as substrates. In vitro potted plants of highbush blueberry cv. Patriot were spaced $1.5 \mathrm{~m}$ apart in a row and $2.5 \mathrm{~m}$ between the rows. The experiment was conducted in 2005-2007. The physical properties of the substrates tested in the experiment are shown in Table 1. Soil samples were taken from each replicate of substrate and from the soil, with a sample stick, in mid-August. Among the substrates, peat had the highest and sawdust had the lowest field water capacity $(44.8 \%$ and $31.3 \%$ 
Vol. 19(2010): 69-80.

Table 1. Water capacity, $\mathrm{pH}$ and salinity of the substrates used for blueberry cultivation

\begin{tabular}{lccc}
\hline & Peat & Cocoa husk & Sawdust \\
\hline $\begin{array}{l}\text { Field water capacity } \\
\left(\% \mathrm{vv}^{-1}\right)\end{array}$ & 44.8 & 36.9 & 31.3 \\
$\begin{array}{l}\text { Full water capacity } \\
\left(\% \mathrm{vv}^{-1}\right)\end{array}$ & 80.6 & 85.3 & 82.6 \\
$\mathrm{pH}^{\mathrm{b}}$ & 3.40 & 5.00 & 4.70 \\
$\begin{array}{l}\text { Soil salinity } \\
(\mathrm{g} \mathrm{NaCl} \mathrm{kg})^{\mathrm{c}}\end{array}$ & 0.87 & 0.35 & 0.56 \\
\hline
\end{tabular}

a Water capacity of soil was measured with the gravimetric method in spring 2005.

${ }^{\mathrm{b}}$ The reaction of substrates was measured with the conductometric method in $\mathrm{KCl}$ at the end of highbush blueberry vegetative season. $\mathrm{pH}$ values are the mean for 2005-2007.

cSoil salinity was measured with the conductometric method and the values are the mean for 2005-2007.

respectively), while cocoa husk had the highest full water capacity $(85.3 \%)$. These differences necessitated the use of varied watering rates.

Fertilization was limited to nitrogen supply only, because chemical analyses of both the soil and substrates showed a high and/or a medium content of other nutrients. Each type of media was fertilized with ammonium nitrate on three occa- sions at a total dose of $30 \mathrm{~kg} \mathrm{~N} \mathrm{ha}^{-1}$. Supplemental irrigation with acidified water (with $\mathrm{H}_{2} \mathrm{SO}_{4}$ up to $\mathrm{pH}$ of 2.5-3.5 measured in $\mathrm{H}_{2} \mathrm{O}$ ) was applied through a $\mathrm{T}$-Tape drip line. The rate of water supply was adjusted to soil moisture content based on the results of tensiometric monitoring expressed in $\mathrm{pF}$ units $(\mathrm{pF}$ - soil suction being the logarithm of water height in centimeters), carried out twice a week. Measuring tubes $(30 \mathrm{~cm})$ were installed $15 \mathrm{~cm}$ below the soil surface, and $\mathrm{pF} 2.2$ was adopted as a threshold value for irrigation. Having reached the threshold, the soil was irrigated to approximately $\mathrm{pF}$ 1.0. Due to the wide range of substrate reaction, water used for irrigation was acidified to a different degree. Water used for peat irrigation had higher $\mathrm{pH}$ (3.72) because peat reaction was suitable for blueberry cultivation, while cocoa husk and sawdust beds were irrigated with water with $\mathrm{pH}$ of 2.36 to lower the reaction of these media (Table 2). Among the substrates tested, peat maintained a constant $\mathrm{pH}$ level of 3.3-3.5 during the field trials, while cocoa husk had the highest reaction ( $\mathrm{pH}$ of 4.6-6.4) (data not shown). $\mathrm{pH}$ and EC were measured with a multi-function computer device CX-741 Elmetron (Zabrze, Poland).

The content of available $\mathrm{Ca}, \mathrm{Na}, \mathrm{Fe}, \mathrm{Mn}, \mathrm{Zn}$ and $\mathrm{Cu}$ in the soil and in the substrates was determined by the AAS method (Atomic Absorption Spectrometry) prior to sample extraction with 0.1

Table 2. Physicochemical properties of water used in the experiment (on average for 2005-2007).

\begin{tabular}{lccccccc}
\hline Raw water & & \multicolumn{3}{c}{$\begin{array}{c}\text { Acidified water for sawdust } \\
\text { and cocoa husk }\end{array}$} & \multicolumn{3}{c}{ Acidified water to irrigate peat } \\
\hline $\mathrm{Fe}^{+3}\left(\mathrm{mg} \cdot l^{-1}\right)$ & $\mathrm{Ca}^{+2}\left(\mathrm{mg} \cdot \mathrm{l}^{-1}\right)$ & $\mathrm{EC}\left(\mathrm{mS} \cdot \mathrm{cm}^{-1}\right)$ & $\mathrm{pH}$ & $\begin{array}{c}\mathrm{EC} \\
\left(\mathrm{mS} \cdot \mathrm{cm}^{-1}\right)\end{array}$ & $\mathrm{pH}$ & $\begin{array}{c}\mathrm{EC} \\
\left(\mathrm{mS} \cdot \mathrm{cm}^{-1}\right)\end{array}$ & $\mathrm{pH}$ \\
0.17 & 94.0 & 0.80 & 7.01 & 2.46 & 2.36 & 2.01 & 3.72 \\
\hline
\end{tabular}

${ }^{*}$ The values are the mean of 2005-2007. The measurements were carried out three times in each year of experiment. $\mathrm{Fe}^{3+}$ and $\mathrm{Ca}^{2+}$ were determined by the AAS method (Atomic Absorption Spectrometry), and EC (Electrical Conductance) and pH were measured with a conductometric method.

Table 3. The content of available macro- and microelements in the grey brown podsolic soil used in the experiment (an average for 2005-2007).

\begin{tabular}{|c|c|c|c|c|c|c|c|c|}
\hline $\mathrm{P}$ & $\mathrm{K}$ & $\mathrm{Ca}$ & $\mathrm{Mg}$ & $\mathrm{Na}$ & $\mathrm{Fe}$ & $\mathrm{Mn}$ & $\mathrm{Zn}$ & $\mathrm{Cu}$ \\
\hline \multicolumn{5}{|c|}{$\left(\mathrm{mg} \cdot 100 \mathrm{~g}^{-1}\right)$} & \multicolumn{4}{|c|}{$\left(\mathrm{mg} \cdot \mathrm{kg}^{-1}\right)$} \\
\hline 12.41 & 35.6 & 70.6 & 5.67 & 1.25 & 102.8 & 66.5 & 17.9 & 2.7 \\
\hline
\end{tabular}


Ochmian, I. et al. Effect of substrates on highbush blueberry 'Patriot'

$\mathrm{M} \mathrm{HCl}$. Soil samples for phosphorus and potassium analyses were extracted according to the EgnerRiehm method, and the concentrations of these elements were determined by a colorimetric and flame atomic emission, respectively. Soil samples for magnesium content estimation were extracted by the Schachtschabel method, and Mg levels were measured by the AAS

For macro- and microelement analyses in plant material, one hundred leaves of plants grown in the tested substrates were sampled each year at the beginning of August. The leaves were dried, first at room temperature in a shaded place and then at $\sim 45^{\circ} \mathrm{C}$, and were pulverized with a WŻ-1 lab mill. Aliquots of berry samples of each harvest in the season were packed in polyethylene bags $(250 \mathrm{~g})$ and kept frozen $\left(-25^{\circ} \mathrm{C}\right)$. Following fruit collection, all fruit samples for each substrate were combined, thawed at room temperature, and dried (initial temperature $60-70{ }^{\circ} \mathrm{C}$, final $105^{\circ} \mathrm{C}$ ). The dried fruits were pulverized (WŻ-1). The total content of macro- and microelements in leaves and fruits was determined according to the Polish Standards. After mineralization, total nitrogen content was determined by the Kjeldahl method. The concentrations of $\mathrm{K}$ and $\mathrm{Ca}$ were measured by flame atomic absorption spectroscopy, whereas $\mathrm{Mg}, \mathrm{Cu}, \mathrm{Zn}, \mathrm{Fe}$, and $\mathrm{Mn}$ content was determined by atomic emission spectrometry using SAA Solaar. Phosphorus content was determined by the Barton method at a wavelength of $470 \mathrm{~nm}$, and sulphur content - by the turbidimetric method at a wavelength of 490 nm, with a Marcel s 330 PRO spectrophotometer.

For plants grown in each substrate, bush growth rate was estimated and expressed as the total annual shoot length $(\mathrm{cm})$ and the average length of oneyear shoots. Fruit yield was assessed and expressed as $\mathrm{kg}$ per ha. Additionally, the mean weight of 100 fruits $(\mathrm{g})$ was determined and fruit size measurements $(\mathrm{mm})$ at the vertical and horizontal axis were taken. Fruit firmness was measured along the vertical axis (fruit height) and along the horizontal axis (fruit diameter) with a FirmTech 2 apparatus (BioWorks, USA) immediately after harvest and every 7 days during 21-day storage at $2{ }^{\circ} \mathrm{C}$ and $96 \%$ relative air humidity. The firmness of 50 berries selected randomly from every replicate was expressed as a gram-force causing fruit surface to bend $1 \mathrm{~mm}$.

Titratable acidity, the content of total sugars, soluble solids, L-ascorbic acid, nitrates and nitrites, and antioxidant capacity were determined in fresh fruit soon after harvest. Titratable acidity was determined by titration of the water extract of blueberry homogenate with $0.1 \mathrm{~N} \mathrm{NaOH}$ to the end point of $\mathrm{pH} 8.1$, according to PN-90/A-75101/04. Total sugar content was determined by the LuffSchoorl method. Soluble solids content was determined in berry juice with the use of an Abbé refractometer (PN-90/A-75101/02). L-ascorbic acid content was determined by the iodometric method (Samotus et al. 1982). In order to measure juice extraction efficiency, fruits were homogenized with a blender and heated up to $50{ }^{\circ} \mathrm{C}$. After cooling, 3 $\mathrm{mL}$ of pectinase (Rapidase Super, BE, NC, USA) per $\mathrm{kg}$ of pulp was added. The pulp was left to stand at room temperature for 1 hour, and then it was pressed for $10 \mathrm{~min}$ at a final pressure of 300 $\mathrm{kPa}$ with a laboratory hydraulic press (Oszmiański and Wojdylo 2005). Nitrate and nitrite content was measured with a RQflex 10 reflectometer (Merck). Fruit antioxidant capacity was evaluated by metmyoglobin oxidation inhibition by antioxidants present in fruit extract and compared to that of Trolox (Miller and Rice-Evans 1996). Total antioxidant capacity was expressed as $\mu$ mol Trolox per $\mathrm{g}$ fruit tissue. Phenolics composition of blueberries was determined in fruit samples that were kept frozen $\left(-32{ }^{\circ} \mathrm{C}\right)$ in polyethylene bags $(250-300 \mathrm{~g})$ until analyzed. The $2 \mathrm{~g}$ aliquots of fruit (after thawing) were extracted three times with approx. $8 \mathrm{~mL}$ of $80 \% \mathrm{MeOH}$ acidified with a glacial acetic acid ( $1 \mathrm{~mL}$ of $100 \%$ acetic acid per $1 \mathrm{~L} 80 \% \mathrm{MeOH}$ ) in an ultrasonic bath for $15 \mathrm{~min}$. The samples were filtered and transferred to the flasks and made up to the final volume $25 \mathrm{~mL}$. Further, the extracts were centrifuged twice at $12,000 \mathrm{x}$ g and $20 \mu \mathrm{L}$ of supernatants were injected into the HPLC system. The HPLC apparatus consisted of a Merck-Hitachi L-7455 diode array detector (DAD) and quaternary pump L-7100 equipped with D-7000 HSM Multisolvent Delivery System (Merck-Hitachi, Tokyo, Japan). The separation was performed on a Cadenza CD C18 $(75 \times 4.6 \mathrm{~mm}, 5 \mathrm{~mm})$ column 
Vol. 19(2010): 69-80.

(Imtakt, Japan). Column oven temperature was set at $30{ }^{\circ} \mathrm{C}$. The mobile phase was composed of solvent $\mathrm{A}$ (4.5\% formic acid), $\mathrm{pH} 2.2$ ) and solvent $\mathrm{B}$ (acetonitrile). The program began with a linear gradient from $0 \% \mathrm{~B}$ to $21 \% \mathrm{~B}(0-30 \mathrm{~min})$, followed by washing and reconditioning the column. The flow rate was $1 \mathrm{~mL} \mathrm{~min}^{-1}$ and the runs were monitored at the following wavelengths: chlorogenic acid at $320 \mathrm{~nm}$, flavonols glycosides (quercetin and kaempferol derivatives) at $360 \mathrm{~nm}$, and anthocyanin glycosides at $520 \mathrm{~nm}$. The Photo Diode Array spectra were measured over the wavelength range $200-600 \mathrm{~nm}$ in steps of $2 \mathrm{~nm}$. Retention times and spectra were compared to those of pure standards within 200-600 nm. Standards of anthocyanidin glycosides and chlorogenic acid were obtained from Polyphenols Laboratories (Norway), while, kaempferol 3- rutinoside and quercetin glycosides from Extrasynthese (France). Except for phenolics, the all measurements of bushes, leaves and fruits were performed for each year of the experiment. Phenolic patterns for berries were determined in 2006 and 2007.

The results obtained were subjected to statistical analysis using Statistica 7.1 (Statsoft, Poland). The values were evaluated by the Duncan test and for phenolics by the Student test. The differences between the means at $p<0.05$ were considered significant.

\section{Results and discussion}

Data relating to plant growth, yield, fruit size and weight of blueberries cv. Patriot are presented in Table 4. Three-year observations of highbush blueberry development showed that peat was the most stimulating medium, superior to sawdust and cocoa husk with regard to total annual shoot length and average oneyear shoot length. Kozinski (2006) observed a higher growth rate of one-year-old shoots when blueberry was grown in soil mixed and mulched with sawdust compared to soil mixed and mulched with bark as well as in pure mineral soil (as control treatment).

In this experiment the vegetative growth of plants was not parallel to their productivity. Among the substrates tested, the highest yield was obtained from bushes grown in sawdust $\left(3.661 \mathrm{~kg} \mathrm{ha}^{-1}\right.$ per season on average), whereas plants grown in cocoa husk were characterized by the lowest productivity (1.315 $\mathrm{kg} \mathrm{ha}^{-1}$ per season on average). The values are so low due to frost damage in 2006. However, despite of unfavorable weather conditions, this species allows multi-annual utilization of plantings, though its productivity is conditioned by the age of bushes and agronomic practices involved, too. In a study conducted by Ciordia et al. (2006), the yield of southern highbush cultivars grown in plas-

Table 4. Growth vigour, yield, weight of 100 fruits, and fruit size of 'Patriot' cv. highbush blueberry depending on substrate type (an average for 2005-2007)

\begin{tabular}{|c|c|c|c|}
\hline Type of substrate & Peat & Sawdust & Cocoa husk \\
\hline Total annual shoot length $(\mathrm{cm})$ & $401 \mathrm{~b}$ & $311 \mathrm{a}$ & $315 \mathrm{a}$ \\
\hline Mean length of one-year shoots $(\mathrm{cm})$ & $46.0 \mathrm{~b}$ & $37.7 \mathrm{ab}$ & $33.0 \mathrm{a}$ \\
\hline Mean yield $\left(\mathrm{kg} \cdot \mathrm{ha}^{-1}\right)$ & $2,639 \mathrm{~b}$ & $3,661 \mathrm{c}$ & $1,315 \mathrm{a}$ \\
\hline Mean weight of 100 fruits (g) & $140 \mathrm{~b}$ & $126 \mathrm{a}$ & $120 \mathrm{a}$ \\
\hline \multirow{2}{*}{ Fruit size (mm) } & $14.50 \mathrm{~b}$ & $15.15 \mathrm{~b}$ & $12.15 \mathrm{a}$ \\
\hline & $17.85 \mathrm{~b}$ & $17.85 \mathrm{~b}$ & $16.35 \mathrm{a}$ \\
\hline \multirow{2}{*}{$\begin{array}{l}\text { Fruit size reduction between begin- } \\
\text { ning and end of harvest }(\%)\end{array}$} & -34.3 & -37.6 & -31.6 \\
\hline & -46.6 & -62.1 & -48.9 \\
\hline
\end{tabular}

$\mathrm{h}^{\mathrm{a}}$ - fruit size measured along fruit height (at vertical axis)

$\varnothing^{\mathrm{b}}$ - fruit size measured along fruit diameter (at horizontal axis) 
Ochmian, I. et al. Effect of substrates on highbush blueberry 'Patriot'

tic tunnels, measured over four years, ranged from 411.36 to $1990.90 \mathrm{~g} \mathrm{plant}^{-1}$. Glonek and Komosa (2006) determined an average yield of 4.530-5.557 $\mathrm{kg}$ per bush for 10-year-old highbush blueberry cv. Bluecrop, depending on fertilization. Smolarz et al. (2006) reported that the productivity of 25-year-old 'Bluecrop' bushes under different fertilization conditions was 2.90-20.77 t per ha.

The highest weight of 100 fruits was found for berries originating from bushes bedded in peat (140 g). Plants grown in sawdust (126 g) and cocoa husk $(120 \mathrm{~g})$ provided smaller fruits. Strik et al. (2003) noted much higher fruit weight for 'Bluecrop' berries, ranging from 130 to $220 \mathrm{~g}$ (after conversion) and even higher for 'Berkeley' berries, between 180 and $260 \mathrm{~g}$ (after conversion). One-fruit weight measured by Heiberg and Stubhaug (2006) varied from 1.81 to $2.86 \mathrm{~g}$, depending on cultivar and location. 'Patriot' berries are slightly flattened, which can be seen when comparing fruit diameter and height (Table 4). The highest dimensions were determined for berries from bushes grown in sawdust, whereas the lowest for those from bushes grown in cocoa husk. However, the largest berries (sawdust) did not have the highest weight of 100 fruits, while the smallest berries (cocoa husk) had the lowest 100-fruit weight. Fruit size reduction was observed towards the end of the harvest season. Fruit diameter was dramatically reduced, particularly in berries from bushes grown in sawdust (by 62\%), whereas fruit height was reduced to a lesser degree $(>30 \%)$. Under field conditions, precipitation shortage or the lack of watering at the end of the growing season substantially contribute to fruit size reduction. Ciordia et al. (2006) tested six southern blueberry cultivars grown in trenches under tunnels, and observed in most varieties a decline in the weight of late-harvest berries equal to or less than $1 \mathrm{~g}$, which made them unacceptable for the fresh fruit market.

The all berries showed higher values of firmness when it was measured along the vertical axis (fruit height) compared with the horizontal axis (fruit diameter) (Table 5). As regards fruit hardness at diameter position, berries from bushes grown in cocoa husk (the smallest ones) showed the highest bending resistance $\left(210 \mathrm{G} \mathrm{mm}^{-1}\right)$ and the lowest drop in firmness during 21-day cold storage $\left(2{ }^{\circ} \mathrm{C}, 96 \%\right.$ humidity). The highest firmness measured along the fruit height axis $\left(492 \mathrm{G} \mathrm{mm}^{-1}\right)$ and the lowest decline in hardness (by 6.1\%) were found for berries from plants grown in sawdust (the biggest ones). Berries from bushes bedded in peat ( as big as those from plants grown in sawdust) showed the lowest firmness measured along the horizontal and vertical axis (184 and $440 \mathrm{G} \mathrm{mm}^{-1}$, respectively) and the greatest decline in hardness (by 8.7 and $8.18 \%$, respective-

Table 5. Changes of firmness for 'Patriot' blueberries after the harvest and during storage in a cold room $\left(2{ }^{\circ} \mathrm{C}, 96 \%\right.$ relative air humidity) on average for 2005-2007.

\begin{tabular}{|c|c|c|c|c|c|}
\hline Storage time & After harvest & $\begin{array}{l}\text { 7-day } \\
\text { storage }\end{array}$ & $\begin{array}{l}\text { 14-day } \\
\text { storage }\end{array}$ & $\begin{array}{l}\text { 21-day } \\
\text { storage }\end{array}$ & $\begin{array}{c}\text { Firmness changes after 21-day } \\
\text { storage }(\%)\end{array}$ \\
\hline Substrate & \multicolumn{5}{|c|}{ Fruit firmness measured at diameter $\left(\mathrm{G} \mathrm{mm}^{-1}\right)$} \\
\hline Peat & 184 & 180 & 175 & 168 & $-8.70 a$ \\
\hline Sawdust & 198 & 195 & 189 & 183 & $-7.58 \mathrm{ab}$ \\
\hline Cocoa husk & 210 & 207 & 200 & 195 & $-7.14 b$ \\
\hline \multirow[t]{2}{*}{ Mean } & $197 \mathrm{~b}$ & $194 \mathrm{ab}$ & $188 \mathrm{ab}$ & $182 \mathrm{a}$ & \\
\hline & \multicolumn{5}{|c|}{ Fruit firmness measured at height axis $\left(\mathrm{G} \mathrm{mm}^{-1}\right)$} \\
\hline Peat & 440 & 435 & 429 & 404 & $-8.18 \mathrm{a}$ \\
\hline Sawdust & 492 & 490 & 478 & 462 & $-6.10 b$ \\
\hline Cocoa husk & 472 & 462 & 456 & 442 & $-6.36 b$ \\
\hline Mean & $468 \mathrm{c}$ & $462 \mathrm{bc}$ & $454 \mathrm{~b}$ & $436 \mathrm{a}$ & \\
\hline
\end{tabular}


Vol. 19(2010): 69-80.

ly). Thus, in terms of handling, these berries would be most sensitive to up- and side-pressure.

The substrates tested in this experiment differed with respect to nutrient abundance (Table 6). In general, cocoa husk was abundant in $\mathrm{P}$ and $\mathrm{Zn}$, sawdust was particularly rich in $\mathrm{Mn}$ and $\mathrm{Cu}$ but had a low $\mathrm{Ca}$ and $\mathrm{Mg}$ content, whereas peat had the lowest $\mathrm{K}$ content. Regardless of the substrate, blueberry leaves had higher amounts of total $\mathrm{N}, \mathrm{Ca}, \mathrm{Mg}, \mathrm{Fe}$ and $\mathrm{Mn}$, compared to fruits (Table 7). The highest $\mathrm{N}$ content was found in the leaves of plants grown in sawdust and in the fruits of plants grown in cocoa husk. According to Hanson (2006), the optimal N content of blueberry leaves picked in mid- summer amounts to $1.7-2.1 \%$. After conversion the above data it can be seen that the $\mathrm{N}$ content of berry leaves was sufficient. Fruit $\mathrm{N}$ content was approximately half of leaf $\mathrm{N}$ content, and the values obtained were lower compared to 1.7-2.8\% determined by Skupień (2004) in four blueberry cultivars.

In this study, plants cultivated in cocoa husk had the highest concentration of $\mathrm{P}$ and $\mathrm{K}$, both in the leaves and fruits. The leaf $\mathrm{P}$ status varying from 1.11 to $1.26 \mathrm{~g} \mathrm{~kg}^{-1}$ was lower than that reported by Glonek and Komosa (2006) for cv. Bluecrop (0.18$0.20 \%$ ), while leaf K levels in cv. Patriot (5.15-6.99 $\mathrm{g} \mathrm{kg}^{-1}$ ) were similar to those determined by these authors in cv. Bluecrop (0.56-0.58\%). Fruit K levels measured in this study $\left(5.18-6.51 \mathrm{~g} \mathrm{~kg}^{-1}\right)$ were lower compared to the values obtained by Skupien (2004) $(0.738-0.855 \%)$.

Table 6. The available macro- and microelements content in the tested substrates on average for 2005-2007.

\begin{tabular}{|c|c|c|c|c|c|c|c|c|}
\hline & $\mathrm{P}$ & $\mathrm{K}$ & $\mathrm{Ca}$ & $\mathrm{Mg}$ & $\mathrm{Fe}$ & $\mathrm{Mn}$ & $\mathrm{Zn}$ & $\mathrm{Cu}$ \\
\hline & \multicolumn{4}{|c|}{$\left(\mathrm{mg} \cdot 100 \mathrm{~g}^{-1}\right)$} & \multicolumn{4}{|c|}{$\left(\mathrm{mg} \cdot 100 \mathrm{~g}^{-1}\right)$} \\
\hline Peat & $13.04 \mathrm{~b}$ & $29.65 \mathrm{a}$ & $170.1 \mathrm{~b}$ & $28.62 \mathrm{~b}$ & $202 \mathrm{a}$ & $32.03 \mathrm{a}$ & $12.65 \mathrm{a}$ & $1.81 \mathrm{a}$ \\
\hline Sawdust & $7.54 \mathrm{a}$ & $52.49 \mathrm{~b}$ & $83.4 \mathrm{a}$ & $21.94 \mathrm{a}$ & $231 \mathrm{ab}$ & $56.47 \mathrm{~b}$ & $25.93 \mathrm{a}$ & $7.36 \mathrm{~b}$ \\
\hline Cocoa husk & $17.16 \mathrm{c}$ & $51.26 \mathrm{~b}$ & $208.5 \mathrm{~b}$ & $26.71 \mathrm{~b}$ & $279 b$ & $24.13 \mathrm{a}$ & $51.66 \mathrm{~b}$ & $1.58 \mathrm{a}$ \\
\hline
\end{tabular}

Table 7. Total macro- and microelements content in leaf and fruit of blueberry 'Patriot' on average for 2005-2007.

\begin{tabular}{|c|c|c|c|c|c|c|}
\hline \multirow{2}{*}{$\begin{array}{l}\text { Macro- and } \\
\text { microelementsa }\end{array}$} & \multicolumn{3}{|l|}{ Leaves } & \multicolumn{3}{|c|}{ Eruit } \\
\hline & \multicolumn{6}{|c|}{$\left(\mathrm{g} \cdot \mathrm{kg}^{-1}\right)$} \\
\hline Total N & $21.81 \mathrm{a}$ & $23.06 \mathrm{~b}$ & $21.45 \mathrm{a}$ & $12.27 \mathrm{a}$ & $12.94 \mathrm{a}$ & $14.25 \mathrm{~b}$ \\
\hline $\mathrm{P}$ & $1.13 \mathrm{a}$ & $1.11 \mathrm{a}$ & $1.26 \mathrm{~b}$ & $0.79 \mathrm{a}$ & $0.90 \mathrm{a}$ & $1.17 \mathrm{~b}$ \\
\hline $\mathrm{K}$ & $5.74 \mathrm{a}$ & $5.15 \mathrm{a}$ & $6.99 \mathrm{~b}$ & $5.18 \mathrm{a}$ & $5.35 \mathrm{a}$ & $6.51 \mathrm{~b}$ \\
\hline $\mathrm{Ca}$ & $3.38 \mathrm{~b}$ & $3.05 \mathrm{~b}$ & $1.54 \mathrm{a}$ & $0.12 \mathrm{~b}$ & $0.10 \mathrm{ab}$ & $0.08 \mathrm{a}$ \\
\hline $\mathrm{Mg}$ & $1.71 \mathrm{~b}$ & $1.48 \mathrm{ab}$ & $1.14 \mathrm{a}$ & $0.27 \mathrm{a}$ & $0.58 \mathrm{~b}$ & $0.26 \mathrm{a}$ \\
\hline \multirow[t]{2}{*}{$\mathrm{S}$} & $1.73 \mathrm{a}$ & $1.60 \mathrm{a}$ & $1.48 \mathrm{a}$ & $1.38 \mathrm{~b}$ & $1.05 \mathrm{a}$ & $1.32 \mathrm{~b}$ \\
\hline & \multicolumn{6}{|c|}{$\left(\mathrm{mg} \cdot \mathrm{kg}^{-1}\right)$} \\
\hline $\mathrm{Cu}$ & $2.72 \mathrm{ab}$ & $3.89 \mathrm{~b}$ & $1.75 \mathrm{a}$ & $1.53 \mathrm{a}$ & $3.01 \mathrm{~b}$ & $1.87 \mathrm{a}$ \\
\hline $\mathrm{Zn}$ & $9.41 \mathrm{a}$ & $10.16 \mathrm{~b}$ & $9.64 \mathrm{a}$ & $6.60 \mathrm{a}$ & $5.66 \mathrm{a}$ & $8.78 \mathrm{~b}$ \\
\hline $\mathrm{Fe}$ & $58.67 \mathrm{a}$ & $58.93 \mathrm{a}$ & $52.91 \mathrm{a}$ & $23.67 \mathrm{a}$ & $21.64 \mathrm{a}$ & $22.78 \mathrm{a}$ \\
\hline $\mathrm{Mn}$ & $199.89 \mathrm{~b}$ & $170.46 \mathrm{~b}$ & $121.04 \mathrm{a}$ & $24.49 \mathrm{a}$ & $23.03 \mathrm{a}$ & $22.73 \mathrm{a}$ \\
\hline
\end{tabular}

$\mathrm{a}_{\text {The values are calculated on dry weight basis }}$ 
Ochmian, I. et al. Effect of substrates on highbush blueberry 'Patriot'

In cv. Patriot, higher concentrations of $\mathrm{Ca}, \mathrm{Mg}$, and $\mathrm{S}$ were recorded in the leaves of bushes grown in peat. Glonek and Komosa (2006) determined the following values in blueberry leaves: $0.64-0.78 \%$ $\mathrm{Ca}, 0.15-0.16 \% \mathrm{Mg}$, and $0.11-0.12 \% \mathrm{~S}$. A comparison of these data with our results shows that $\mathrm{Ca}$ levels in the leaves of blueberries grown in the tested substrates were distinctly lower, whereas $\mathrm{Mg}$ and $\mathrm{S}$ content was similar. Fruit $\mathrm{S}$ content in 'Patriot' berries $\left(>1.0 \mathrm{~g} \mathrm{~kg}^{-1}\right)$ was higher, compared to control lingonberries analyzed by Levula et al. (2000) $(>700$ $\left.\mathrm{mg} \mathrm{kg}^{-1}\right)$. 'Patriot' berries showed a lower fruit $\mathrm{Ca}$ content $\left(0.08-0.12 \mathrm{~g} \mathrm{~kg}^{-1}\right)$ and a higher fruit $\mathrm{Mg}$ content $\left(0.26-0.58 \mathrm{~g} \mathrm{~kg}^{-1}\right)$, in comparison with blueberries studied by Skupień (2004) (0.127-0.191\% and $0.016-0.018 \%$, respectively). The low leaf $\mathrm{Ca}$ and fruit Ca levels observed in this study could result from better acidification of the substrates used. As regards between-substrate differences, 'Patriot' berries from plants grown in peat had the highest $\mathrm{Ca}$ content. The highest fruit S levels were determined for berries originating from cocoa husk and peat beddings, whereas berries from plants grown in sawdust were richest in $\mathrm{Mg}$.

Plants cultivated in substrates rich in microelements showed elevated concentrations of microelements in the leaves and fruits (Table 7). The highest $\mathrm{Cu}$ levels were noted in the leaves and fruits of 'Patriot' bushes grown in sawdust $\left(3.89 \mathrm{mg} \mathrm{kg}^{-1}\right.$ and $3.01 \mathrm{mg} \mathrm{kg}^{-1}$, respectively) which was most abundant in $\mathrm{Cu}$. Interestingly, the leaves and berries of plants grown in peat and cocoa husk had similar $\mathrm{Cu}$ levels as the respective substrates. As regards sawdust, leaf $\mathrm{Cu}$ and fruit $\mathrm{Cu}$ concentrations corresponded to the values (3.37-3.88 ppm) observed by Glonek and Komosa (2006) for the leaves of cv. Bluecrop, whereas fruit $\mathrm{Cu}$ content reported by Skupień (2004) was much lower (0.138-0.303 mg $\left.\mathrm{kg}^{-1}\right)$. The highest $\mathrm{Zn}$ concentrations determined in 'Patriot' leaves (sawdust) and fruits (cocoa husk) in this study were correlated with $\mathrm{Zn}$ abundance in the medium. Leaf Zn content at 9.41-10.16 $\mathrm{mg} \mathrm{kg}^{-1}$ was lower than that reported by Merhaut and Darnell

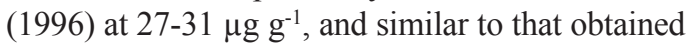
by Glonek and Komosa (2006) at 7.98-8.38 ppm. Fruit $\mathrm{Zn}$ content $\left(5.66-8.78 \mathrm{mg} \mathrm{kg}^{-1}\right.$ ) was higher than that determined by Skupien (2004) at 1.081-1.30 $\mathrm{mg} \mathrm{kg}{ }^{-1}$.

The all substrates tested as growing media for blueberry cv. Patriot showed high Fe concentrations

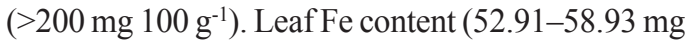
$\left.\mathrm{kg}^{-1}\right)$ was very close to the range of 53.9-57.7 ppm reported by Glonek and Komosa (2006) and higher than the $36-37 \mu \mathrm{g} \mathrm{g}^{-1}$ range determined by Merhaut and Darnell (1996). On the other hand, fruit Fe content in blueberry cv. Patriot was $\sim 50 \%$ that of leaf Fe content, however it was still higher than 14-15 $\mathrm{mg} \mathrm{kg}^{-1}$ reported for lingonberries by Levula et al. (2000). Despite statistical differences between the media tested, no significant differences were found for leaf and fruit $\mathrm{Fe}$ content.

Table 8. Blueberry 'Patriot' fruit chemical composition in dependence on the type of substrate (an average for 2005-2007).

\begin{tabular}{lccc}
\hline Item $^{\mathrm{a}}$ & Peat & Sawdust & Cocoa husk \\
\hline Soluble solids $(\%)$ & $12.4 \mathrm{a}$ & $13.1 \mathrm{~b}$ & $11.7 \mathrm{a}$ \\
Total sugar $\left(\mathrm{g} \cdot 100 \mathrm{~g}^{-1}\right)$ & $9.71 \mathrm{a}$ & $10.80 \mathrm{~b}$ & $9.85 \mathrm{a}$ \\
Titratable acidity $\left(\mathrm{g}\right.$ citric acid $\left.\cdot 100 \mathrm{~g}^{-1}\right)$ & $2.41 \mathrm{~b}$ & $2.35 \mathrm{~b}$ & $1.98 \mathrm{a}$ \\
L-ascorbic acid $\left(\mathrm{mg} \cdot 100 \mathrm{~g}^{-1}\right)$ & $26.0 \mathrm{~b}$ & $23.4 \mathrm{a}$ & $26.2 \mathrm{~b}$ \\
Juice efficiency $(\%)$ & $89.98 \mathrm{a}$ & $90.29 \mathrm{a}$ & $89.88 \mathrm{a}$ \\
$\mathrm{N}-\mathrm{NO}_{2}\left(\mathrm{mg} \cdot \mathrm{kg}^{-1}\right)$ & $0.75 \mathrm{a}$ & $0.95 \mathrm{~b}$ & $0.85 \mathrm{ab}$ \\
$\mathrm{N}-\mathrm{NO}_{3}\left(\mathrm{mg} \cdot \mathrm{kg}^{-1}\right)$ & $19.3 \mathrm{a}$ & $31.4 \mathrm{~b}$ & $24.6 \mathrm{ab}$ \\
$\mathrm{TEAC}\left(\mu \mathrm{mol} \mathrm{Trolox} \cdot \mathrm{g}^{-1}\right)$ & $38.6 \mathrm{~b}$ & $35.7 \mathrm{a}$ & $35.3 \mathrm{a}$ \\
\hline
\end{tabular}

${ }^{a}$ The values are presented on fresh weight basis

TEAC - Trolox Equivalent Antioxidant Capacity 
Vol. 19(2010): 69-80.

The highest Mn levels were recorded in the leaves of plants grown in peat and sawdust (Mnrichest substrates) however the type of substrate did not affect fruit Mn content. Leaf Mn concentrations determined for cv. Patriot (121.04-199.89 mg kg$\left.{ }^{1}\right)$ were higher than those found for cv. Bluecrop (107.6-128.0 ppm) (Glonek and Komosa 2006), and both ranges were higher than the value of $44-57 \mu \mathrm{g}$ $\mathrm{g}^{-1}$ reported by Merhaut and Darnell (1996). On the other hand, 'Patriot' berries had a low Mn content, ranging from $21.64 \mathrm{mg} \mathrm{kg}^{-1}$ (sawdust) to $23.67 \mathrm{mg}$ $\mathrm{kg}^{-1}$ (peat).

'Patriot' berries obtained from sawdust-grown bushes had the highest soluble solids (13.1\%) and

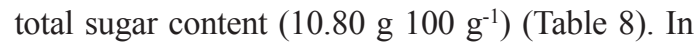
the study conducted by Skupien (2004) the soluble solids content of blueberry cultivars mulched with sawdust was determined within a similar range of 11.6-13.8\%. Prior et al. (1998) observed greater variation in soluble solids content (10.0-19.0\%), affected by the cultivar, geographical location and harvest date. Total sugar content found in this inves-

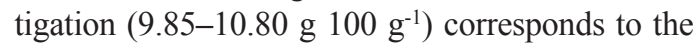
sum of glucose and fructose reported by Wang et al. (2008) for blueberries in a conventional culture

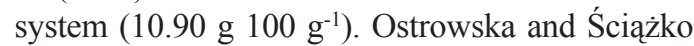
(1996) determined a slightly lower total sugar con-

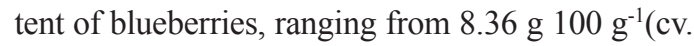

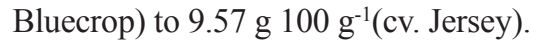

Total acid content observed in this study was 1.98-2.41 g citric acid $100 \mathrm{~g}^{-1}$ (Table 8). Higher acidity was observed in the berries of bushes bedded in peat and sawdust. Rosenfeld et al. (1999) determined acid concentrations at $0.82 \%$ in 'Bluecrop' berries stored at $4{ }^{\circ} \mathrm{C}$. L-ascorbic acid content determined for 'Patriot' berries varied from $23.4 \mathrm{mg}$

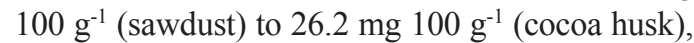
and was not affected by the type of substrate (Table 8). Łata et al. (2005) reported vitamin C content of 16.6-30.6 mg $100 \mathrm{~g}^{-1}$ in blueberries, depending on the cultivar and seasonal variations.

Juice efficiency measured for 'Patriot' berries was high (89.9-90.9\%) and not medium-dependent (Table 8). Rossi et al. (2003) obtained a lower juice yield for blueberries, amounting to $79-81 \%$, which could result from a different extraction procedure.
The nitrite content of blueberries obtained from plants grown in all media tested in the study was below $1 \mathrm{mg} \mathrm{kg}^{-1}$ (Table 8), which is consistent with Polish regulations concerning, among others, apple juice, fruit-vegetable juices and banana-containing products for babies and young children under three. Blueberries are characterized by low nitrate accumulation. The values obtained in this study (Table 8) confirm that blueberries are nitrate-safe product and the amounts ranging from $19.9 \mathrm{mg} \mathrm{kg}^{-1}$ (peat) to $31.4 \mathrm{mg} \mathrm{kg}^{-1}$ (sawdust) are fairly below the levels permitted for bananas and vegetables meant for special usage (baby food, etc.) up to $200 \mathrm{mg} \mathrm{kg}^{-1}$.

The antioxidant capacity of blueberries is well substantiated in the literature (Prior et al. 1998, Ehlenfeldt and Prior 2001). In this experiment, blueberries showed TEAC values in the range of 35.3-38.6 $\mu$ mol Trolox $\cdot g^{-1}$ (Table 8). Connor et al. (2002) found lower antioxidant activity for 'Patriot' berries, varying from 20 to $29 \mu \mathrm{mol}$ Trolox $\cdot \mathrm{g}^{-1} \mathrm{de}$ pending on the year of the experiment and location. Ścibisz et al. (2003) observed that early harvested berries showed $29.9 \mu \mathrm{mol}$ Trolox $\cdot \mathrm{g}^{-1}$, whereas lateharvested berries $-61.8 \mu \mathrm{mol}$ Trolox $\cdot \mathrm{g}^{-1}$. A likely reason is that smaller fruits of late harvest have a higher surface:volume ratio. Since in blueberries anthocyanins are found in the skin only, the enhanced amount of these compounds (apart from other phenolics) in smaller berries contributes substantially to their higher antioxidant activity.

The type of substrate exerted a significant influence on total phenolic content (Table 9). Berries from bushes grown in cocoa husk showed the highest amounts of phenolics (208.29 mg $\left.100 \mathrm{~g}^{-1}\right)$, while the lowest value was observed for sawdustoriginating berries (122.43 mg $\left.100 \mathrm{~g}^{-1}\right)$. Connor et al. (2002) measured a total phenol content of 360-569 mg chlorogenic acid equivalents $100 \mathrm{~g}^{-1}$ in 'Patriot' berries. Prior et al. (1998) estimated phenolic content at $181.1-390.5 \mathrm{mg}^{100 \mathrm{~g}^{-1}}$ in blueberry cultivars obtained from different sources. In this study, the amount of total phenols was not in accordance with TEAC values. Berries from plants grown in sawdust and cocoa husk beddings had almost equal antioxidant capacity (35.7 and 35.3 $\mu$ mol Trolox $\mathrm{g}^{-1}$, respectively), whereas the phenol content of berries originating from cocoa husk was 
Ochmian, I. et al. Effect of substrates on highbush blueberry 'Patriot'

Table 9. Influence of substrates on phenolic composition of 'Patriot' blueberries (an average for 2006-2007).

\begin{tabular}{|c|c|c|c|}
\hline & Peat & Sawdust & Cocoa husk \\
\hline & \multicolumn{3}{|c|}{$\mathrm{mg} \cdot 100 \mathrm{~g}^{-1}$} \\
\hline Chlorogenic acid & $39.52 \mathrm{~b}$ & $9.78 \mathrm{a}$ & $82.79 \mathrm{c}$ \\
\hline Cyanidin -3-arabinoside & 5.43 & 3.85 & 2.75 \\
\hline Cyanidin-3-galactoside & 6.14 & 5.37 & 3.56 \\
\hline Cyanidin-3-glucoside & 5.90 & 5.13 & 3.78 \\
\hline Delphinidin-3-arabinoside & 10.94 & 9.74 & 9.64 \\
\hline Delphinidin-3-galactoside & 15.91 & 14.21 & 18.27 \\
\hline Delphinidin-3-glucoside & 19.52 & 17.51 & 24.21 \\
\hline Peonidin-3-arabinoside & 6.92 & 5.47 & 3.09 \\
\hline Peonidin-3-galactoside & 5.92 & 5.57 & 7.19 \\
\hline Peonidin-3-glucoside & 6.71 & 5.20 & 3.50 \\
\hline Petunidin-3-arabinoside & 7.18 & 2.38 & 11.67 \\
\hline Petunidin-3-galactoside & 1.81 & 4.97 & 3.05 \\
\hline Petunidin-3-glucoside & 3.92 & 4.89 & 6.41 \\
\hline Malvidin-3-arabinoside & 9.79 & 7.45 & 9.36 \\
\hline Malvidin-3-galactoside & 10.56 & 8.36 & 4.95 \\
\hline Malvidin-3-glucoside & 5.95 & 4.35 & 3.88 \\
\hline Sum of anthocyanins & $122.6 \mathrm{~b}$ & $104.45 \mathrm{a}$ & $115.31 \mathrm{ab}$ \\
\hline Quercetin-3-galactoside & 5.93 & 4.01 & 5.83 \\
\hline Quercetin-3-glucoside & 1.44 & 1.04 & 1.17 \\
\hline Quercetin-3-ramnoside & 2.07 & 1.46 & 1.94 \\
\hline Kaempferol-3-rutinoside & 2.52 & 1.69 & 1.26 \\
\hline Sum of flavonols & $11.96 \mathrm{a}$ & $8.2 \mathrm{a}$ & $10.2 \mathrm{a}$ \\
\hline Total & $174.07 \mathrm{~b}$ & $122.43 \mathrm{a}$ & $208.29 \mathrm{~b}$ \\
\hline
\end{tabular}

1.7-fold higher than that of sawdust-grown berries. Berries collected from peat-grown bushes showed the highest antioxidant activity $(38.6 \mu \mathrm{mol}$ Trolox $\left.\mathrm{g}^{-1}\right)$, although they had a medium phenolic content

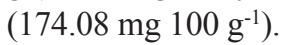

The proportions of phenolics identified in blueberries were as follows: for peat $-70.4 \%$ anthocyanins $>22.7 \%$ chlorogenic acid $>6.9 \%$ flavonols, for sawdust $-85.3 \%$ anthocyanins $>8 \%$ chlorogenic acid $>6.7 \%$ flavonols, for cocoa husk $-55.4 \%$ anthocyanins $>39.7 \%$ chlorogenic acid $>4.9 \%$ flavonols. The greatest differences between berries were observed with respect to chlorogenic acid (Table 9). The berries from plants grown in cocoa husk bedding were richest in chlorogenic acid $(82.79 \mathrm{mg}$ $100 \mathrm{~g}^{-1}$ ) whereas, the chlorogenic acid content of berries from bushes grown in peat and sawdust was $\sim 2$-fold and $\sim 8$-fold lower, respectively. Zheng and Wang (2003) determined lower chlorogenic acid concentrations in blueberry cv. Sierra - $645.9 \mu \mathrm{g}$ $\mathrm{g}^{-1}$. Regardless of substrate type, delphinidin glycosides dominated among anthocyanins (41.4-52.12 mg $100 \mathrm{~g}^{-1}$ ), especially delphinidin 3-glucoside and delphinidin 3-galactoside (Table 9). Cyanidin, peonidin, petunidin and malvidin-glycosides were also detected. Berries originating from peat had a higher content of total anthocyanins (122.6 mg $100 \mathrm{~g}^{-1}$ ), whereas the lowest amounts of these pigments were found in the fruits of sawdust-grown plants (104.45 $\left.\mathrm{mg} 100 \mathrm{~g}^{-1}\right)$. Connor et al. (2002) determined 140$191 \mathrm{mg}$ cyanidin 3 -glucoside equivalents $100 \mathrm{~g}^{-1}$ in 'Patriot' berries, depending on the year of the experi- 
Vol. 19(2010): 69-80.

ment and the growing area. In an experiment performed by Prior et al. (1998), the total anthocyanin content of blueberries varied over a wide range of

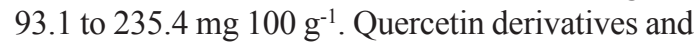
kaempferol 3-rutinoside were also identified, and quercetin 3-galactoside was found to be a predominant flavonol. The total of quercetin derivatives var-

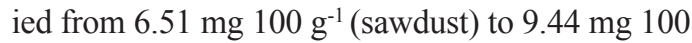
$\mathrm{g}^{-1}$ (peat), and these values were higher compared with the data obtained for blueberries of different varieties and sites by Häkkinen and Törrönen (2000) -2.2-4.7 mg $100 \mathrm{~g}^{-1}$, but lower than those reported by Zheng and Wang (2003) for cv. Sierra (248.7 $\left.\mu \mathrm{g} \mathrm{g}^{-1}\right)$. However, in the present study the type of medium did not significantly affect total flavonol content (8.2-11.96 mg $\left.100 \mathrm{~g}^{-1}\right)$.

\section{Conclusions}

A three-year study of substrates tested as growing media for highbush blueberry cv. Patriot showed that the most intensive bush growth was observed when plants were grown in peat, while the highest yield (on a 3-year average) was attained in plants grown in sawdust. The berries of bushes bedded in sawdust were largest, but they showed the most disadvantageous fruit size reduction as the picking period progressed. On the other hand, these berries demonstrated the highest firmness measured along the vertical axis (fruit height), whereas the berries of bushes grown in cocoa husk had the highest firmness measured along the horizontal axis (fruit diameter).

Irrespective of the substrate used, the leaves of 'Patriot' plants contained larger amounts of $\mathrm{N}, \mathrm{Ca}$, $\mathrm{Mg}, \mathrm{Fe}$ and $\mathrm{Mn}$ than the fruits. As regards particular media, the concentrations of macro- and microelements in leaves and fruits varied, except for leaf Fe, fruit $\mathrm{Fe}$ and fruit $\mathrm{Mn}$ content which showed no correlation with the substrate.

Berries originating from sawdust contained the highest amounts of soluble solids and total sugars, and the lowest L-ascorbic acid levels. For all berries, juice efficiency was high and not substrate-dependent. The accumulation of nitrates and nitrites in blueberry cv. Patriot was low and did not exceed the permissible levels for food items designed for babies and young children.

Berries originating from peat had the highest antioxidant capacity and the highest total anthocyanin content. Delphinidin-glycosides were predominant anthocyanins in all berries. The following phenolics were identified in 'Patriot' berries (in descending order): anthocyanins $>$ chlorogenic acid $>$ flavonols. The proportions of individual compounds were substrate-dependent. Berries originating from the cocoa husk bedding showed the highest content of chlorogenic acid and total polyphenols. On the other hand, the amount of total flavonols was not affected by the type of substrate.

From the quantitative point of view, the best productivity (yield) and consumer attractiveness (fruitsize) were observed for 'Patriot' blueberries grown in sawdust. These berries were richest in N, P, K, $\mathrm{Zn}$, total sugars and soluble solids. However, their most undesirable characteristic was a considerable fruit size reduction at the end of the harvest season, and lower concentrations of anthocyanins and total phenols, compared with berries grown in peat and cocoa husk respectively.

Acknowledgments. The study was supported by the grant of the Scientific Research Committee No.0395/P06/2004/26.

\section{References}

Black B.L., Zimmerman R.H., and Hepp R.F. 2002: Industrial and municipal by products as substrates for highbush blueberry production. Acta Horticulturae 574: 267-272

Castrejón A.D., Eichholz I., Rohn S., Kroh L.W., and Huyskens-Keil S. 2008. Phenolic profile and antioxidant activity of highbush blueberry (Vaccinium corymbosum L.) during fruit maturation and ripening. Food Chemistry 109: 564-572.

Ciordia M., Garcia J.C., and Diaz M.B. 2006. Off-season production of southern highbush blueberries in the North of Spain. Acta Horticulturae 715: 317-322.

Connor A.M., Luby J.J., Tong C.B.S., Finn C.E., and Hancock J.F. 2002. Journal of the American Society for Horticultural Science 127: 89-97.

Glonek J. \& Komosa A. 2006. The effect of fertigation on the nutrient status and yield of highbush blueberry cv. 'Bluecrop'. Acta Horticulturae 715: 371-374.

Ehlenfeldt M.K. \& Prior R.L. 2001. Oxygen radical absorbance capacity (ORAC) and phenolic and anthocyanin 


\section{Ochmian, I. et al. Effect of substrates on highbush blueberry 'Patriot'}

concentration in fruit and leaf tissues of highbush blueberry. Journal of Agricultural and Food Chemistry 49: 2222-2227.

Entrop A.-P. 2000. Der Heidelbeeranbau in den Vereinigten Staaten von Amerika - Teil II. Kulturheidelbeeranbau in Oregon und Florida; Mitteilungendes Obstbauversuchsringes des Alten Landes (Mitt. OVR) 55: 44-53.

Häkkinen S.H. \& Törrönen A.R. 2000. Content of flavonols and selected phenolic acids in strawberries aand Vaccinium species : influence of cultivar, cultivation site and technique. Food Research International 33: 517-524.

Hanson E.J. 2006. Nitrogen fertilization of highbush blueberry. Acta Horticulturae 715: 347-351.

Heiberg N. \& Stubhaug E. 2006. First results from cultivar trials with highbush blueberry in Norway. Acta Horticulturae 715: 307-311.

Internetowa giełda rolna fresh-market. 2009. Available on the internet: http://www.fresh-market.pl/katalog produktow/owoce/borowka_wysoka Online. Cited $1 \overline{9}$ September 2008

Kader R, Rovel B., Girardin M., and Metche M. 1996. Fractionation and identification of the phenolic compounds of Highbush blueberries (Vaccinium corymbosum). Food Chemistry 55: 35-40.

Kalt W., Forney C.F., Martin A., and Prior R.L. 1999. Antioxidant capacity, vitamin C, phenolics, and anthocyanins after fresh storage of small fruits. Journal of Agricultural and Food Chemistry 47: 4638-4644.

Kozinski B. 2006. Influence of mulching and nitrogen fertilization rate on growth and yield of highbush blueberry. Acta Horticulturae 715: 231-235.

Krewer G., Ruter J., NeSmith D. S., Clark J., Otts T., Scarborough S., Mullinix B. and Hepp R. F., 2002. Performance of low cost organic materials as blueberry substrates and soil amendments. Acta Horticulturae 574: 273-279.

Levula T., Saarsalmi A., and Rantavaara A. 2000. Effects of ash fertilization and prescribed burning on macronutrient, heavy metal, sulphur and ${ }^{137} \mathrm{Cs}$ concentrations in lingonberries (Vaccinium vitis-idea). Forest Ecology and Management 126: 269-279.

Lyrene PM. 1997. Value of various taxa in breeding tetraploid blueberries in Florida. Euphytica 94: 15-22.

Łata B., Trąmpczyńska A., and Mike A. 2005. Effect of cultivar and harvest date on thiols, ascorbate and phenolic compounds content in blueberries. Acta Scientiarum Polonorum Hortorum Cultus 4: 163-171.

Mainland C. M., Tucker J. W., and Hepp R. F. 2002. Blueberry health information - some new mostly review. Acta Horticulturae 574: 39-43.

Merhaut D.J. \& Darnell R.L. 1996. Vegetative growth and nitrogen/karbon partitioning In blueberry as influence by nitrogen fertilization. Journal of American Horticultural Society 121: 875-879.

Miller N. J. \& Rice-Evans C. A. 1996. Spectrophotometric determination of antioxidant activity. Redox Report 2: 161-171.

Ostrowska K. \& Ściążko D. 1996. Zawartość składników bioorganicznych i mineralnyc owocach trzech odmian borówki wysokiej. (The contents of bioorganic and mineral components in fruit of three blueberry cultivars). In: II Ogólnopolskie Sympozjum, AR w Poznaniu, p. 225-229.
Oszmiański, J. \& Wojdylo A. 2005: Aronia melanocarpa phenolics and their antioxidant activity. European Food Research and Technology 221: 809-813.

Prior R.L., Cao G., Martin A., Sofic E., McEwen J., O'Brien C., Lischner N., Ehlenfeldt M., Kalt W., Krewer G., and Mainland C.M. 1998. Antioxidant capacity as influenced by total phenolic and anthocyanin content, maturity, and variety of Vaccinium species. Journal of Agricultural and Food Chemistry 46: 2686-2693.

Rosenfeld H.J., Meberg K.R., Haffner K., and Sundell H.A. 1999. Map of Highbush blueberries: sensory quality in relation to storage temperature, film type and initial high oxygen atmosphere. Postharvest Biology and Technology 16: 27-36.

Rossi M., Giussani E., Moreli R., Lo Scalzo R., Nani R.C., and Torreggiani D. 2003. Effect of fruit blanching on phenolics and radical scavenging activity of highbush blueberry juice. Food Research International 36: 999-1005.

Samotus B., Leja M., and Ścigalski A. 1982. Porównanie czterech metod oznaczania kwasu askorbinowego w owocach i warzywach (Comparison of four methods for ascorbic acid determination in fruit and vegetables). Acta Agraria et Silvestria, Ser. Agraria XXI: 105-121.

Skupień K. 2004. Ocena wartości odżywczej czterech odmian borówki wysokiej (Vaccinium corymbosum L.) (Estimation of nutritive value of four cultivars of highbush blueberry fruit (Vaccinium corymbosum L.)). Folia Universitas Agriculturae Stetinensis, Agricultura 240: 171-174.

Smolarz, K. 2006. History of highbush blueberry (V. corymbosum L.) growing in Poland. Acta Horticulturae 715: 313-316.

Smolarz K., Kozinski B., and Chlebowska D. 2006. Krótka informacja o wynikach badań nad mineralnym nawożeniem borówki wysokiej prowadzonych w Instytucie Sadownictwa i Kwiaciarstwa w Skierniewicach. In: Międzynarodowa Konferencja „Uprawa Borówki i Żurawiny" (z elementami ekologii) (A brief report on the results of the experiments on mineral fertilization of highbush blueberry at the Institute of Pomology and Floriculture in Skierniewice. In: International Scientific Conference on 'Blueberry and Cranberry growing' (with ecological aspects)). ISK Skierniewice 19-22 czerwca, p. 63-70.

Strik B. 2005. Blueberry: an expanding world berry crop. Chronicles of Horticulture 45: 7-12.

Strik B., Buller G., and Hellman E. 2003. Pruning severity affects field, berry weight, and hand harvest efficiency of highbush blueberry. HortScience 38: 196-199.

Ścibisz I., Mitek M., and Malewska J. 2003. Aktywność przeciwutleniająca owoców borówki wysokiej (Vaccinium corymbosum L.) (Antioxidant activity of highbush blueberry fruit (Vaccinium corymbosum L.)). Żywność 2(35) Supl.: 159-166.

Wang S.H., Chen C.T., Sciarappa W., Wang C.Y., and Camp M.J. 2008. Fruit quality, antioxidant capacity, and flavonoid content of organically and conventionally grown blueberries. Journal of Agricultural and Food Chemistry 56: 5788-5794.

Zheng W. \& Wang S.Y. 2003. Oxygen radical absorbing capacity of phenolics in blueberries, cranberries, chokeberries, and lingonberries. Journal of Agricultural and Food Chemistry 51: 502-509. 